\title{
PENGATURAN KEGIATAN USAHA PERTAMBANGAN DALAM KAITANNYA DENGAN PENYELESAIAN SENGKETA PERTAMBANGAN
}

\author{
Dewi Tuti Muryati, B. Rini Heryanti, Dhian Indah Astanti \\ Fakultas Hukum, Universitas Semarang
}

\begin{abstract}
ABSTRAKSI
Selaras dengan amanat dari konstitusi Negara Republik Indonesia Pasal 33 Undang-Undang Dasar Negara Republik Indonesia Tahun 1945, pengelolaan dan pengusahaannya dibutuhkan perlindungan dan jaminan kepastian hukum baik kepada masyarakat sebagai common property atas bahan galian, pengusaha sebagai pengelola, dan pemerintah sebagai regulator. Kegiatan usaha pertambangan sering menimbulkan sengketa yang melibatkan pemerintah, pengusaha pertambangan (investor), dan masyarakat di wilayah kegiatan usaha pertambangan. Oleh karena itu perlu diupayakan untuk menyelesaikan sengketa melalui mekanisme penyelesaian sengketa. Permasalahan yang akan diteliti meliputi perkembangan pengaturan kegiatan usaha bidang pertambangan di Indonesia dan mekanisme penyelesaian sengketa di bidang pertambangan dalam rangka menciptakan kepastian hukum dan keadilan. Adapun metode yang digunakan dalam penelitian ini adalah dengan pendekatan yuridis normatif; spesifikasi penelitian adalah deskriptif analitis; data yang digunakan adalah data sekunder yang meliputi bahan hukum primer, bahan hukum sekunder, bahan hukum tersier; kemudian dianalisis secara kualitatif. Berdasar hasil penelitian diketahui bahwa perkembangan pengaturan kegiatan usaha pertambangan di Indonesia sudah ada sejak masa pemerintahan Hindia Belanda dengan berlakunya Indische Mijnwet 1899, setelah merdeka diterbitkan Perpu Nomor 37 Tahun 1960 tentang Pertambangan, Perpu Nomor 44 Tahun 1960 tentang Minyak dan Gas Bumi, UU Nomor 37 Prp. Tahun 1960 tentang Pertambangan, kemudian digantikan dengan UU Nomor 11 Tahun 1967 tentang Ketentuan-Ketentuan Pokok Pertambangan yang kemudian dicabut dan terbit UU Nomor 4 Tahun 2009 tentang Pertambangan Mineral dan Batubara. Adapun mekanisme penyelesaian sengketa pertambangan meliputi adjudikasi, non-adjudikasi, pengadilan, arbitrase, ADR, dan lembaga adat.
\end{abstract}

Kata kunci : pengaturan pertambangan, penyelesaian sengketa.

\begin{abstract}
Consistent with the mandate of the Constitution of the Republic of Indonesia, namely Article 33 of the Constitution of the Republic of Indonesia which, the mining business is risky, then in the management and enterprise required the protection and guarantee of legal certainty both to the public as a common property on minerals, the entrepreneur as a manager, and the government as a regulator. Mining activities often lead to disputes involving government, mining entrepreneurs (investors), and the communities in the mining business . Therefore it is necessary to resolve the dispute through the dispute settlement mechanism so that the party relationships associated with mining activities could be restored as before the occurrence of the dispute. Issues to be examined include the development of organization of mining business activities in Indonesia and the dispute settlement mechanism in the mining sector in order to create legal certainty and justice. The method used in this research is normative juridical approach; specification research is descriptive; Data used is secondary data including primary legal materials, secondary legal materials, tertiary legal materials; later analyzed qualitatively. Based on the survey results revealed that the development of the regulation of mining business activities in Indonesia have existed since the reign of the Dutch East Indies with the enactment Indische Mijnwet 1899, after independence issued Government Regulation No. 37 of 1960 on Mining, Government Regulation No. 44 Year 1960 on Oil and Gas, Law Number 37 Prp. 1960 on Mining, later replaced by Law No. 11 of 1967 concerning Basic Provisions of Mining which was later repealed and published Law No. 4 of 2009 on Mineral and Coal Mining. As for the dispute settlement mechanism includes adjudications, non-adjudication, court, arbitration, ADR, customary institutions.
\end{abstract}

Key word : the regulation of mining, dispute settlement 


\section{PENDAHULUAN}

2.

\section{Latar Belakang Penelitian}

Pertambangan merupakan sektor yang mendapat perhatian serius dari pemerintah, mengingat kegiatan usaha pertambangan tersebut memberikan kontribusi yang cukup besar bagi masuknya devisa negara, hal ini terlihat dengan banyaknya perizinan Kuasa Pertambangan di daerah. Disisi lain dengan meningkatnya jumlah kegiatan usaha pertambangan baik yang melibatkan investasi asing maupun nasional, menimbulkan eksploitasi besar-besaran dan mengakibatkan pencemaran serta rusaknya lingkungan. Disamping itu timbul berbagai masalah terutama adalah penggunaan lahan untuk aktivitas pertambangan, sehingga menimbulkan gesekan kepentingan antara pelaku usaha pertambangan, masyarakat setempat dan pemerintah daerah dimana kegiatan usaha pertambangan tersebut dilakukan.

Sengketa yang timbul dalam kegiatan usaha pertambangan seharusnya dapat diprediksikan atau berusaha menghindari timbulnya konflik baik yang bersumber dari kontrak/ perjanjian yang dibuat oleh para pihak sebelum kegiatan tersebut dilaksanakan maupun ketika pelaksanaan kegiatan, sehingga pelaksana kegiatan dapat meminimalisir sumber timbulnya sengketa. Namun pada umumnya timbulnya sengketa tersebut sulit untuk dihindari, sehingga diperlukan upaya untuk menyelesaikan sengketa tersebut.

Berdasarkan uraian pada latar belakang penelitian, perlu kiranya dilakukan suatu penelitian yang mendalam terhadap pengaturan kegiatan usaha pertambangan dalam kaitannya dengan penyelesaian sengketa pertambangan.

\section{Rumusan Masalah}

Berpijak pada uraian tersebut, maka permasalahan yang akan dikaji dalam penelitian ini adalah :

1. Bagaimanakah perkembangan pengaturan kegiatan usaha bidang pertambangan di Indonesia?

2. Bagaimana mekanisme penyelesaian sengketa di bidang pertambangan dalam rangka menciptakan kepastian hukum dan keadilan?

\section{Tujuan Penelitian}

Tujuan yang ingin dicapai adalah :

1. Untuk mengetahui dan menganalisis perkembangan pengaturan mengenai kegiatan usaha bidang pertambangan di Indonesia.

2. Untuk mengetahui dan menganalisis lebih lanjut mekanisme penyelesaian sengketa di bidang pertambangan dalam rangka menciptakan kepastian hukum dan keadilan.

Manfaat penelitian
1. Memberi gambaran atas perkembangan pengaturan mengenai kegiatan usaha bidang pertambangan di Indonesia.

2. Memberikan sumbangsih wacana dan data bagi para praktisi terutama masalah yang berkaitan dengan penyelesaian sengketa pertambangan, dengan harapan supaya para penegak hukum untuk lebih luas memahami peraturan yang berkaitan dengan penyelesaian sengketa pertambangan sehingga tidak saling berbenturan atau bertentangan.

3. Dapat menjadi masukan bagi pembuat kebijakan, khususnya kebijakan yang berkaitan dengan pengaturan bidang pertambangan, agar dalam pembuatan kebijakan di bidang pertambangan termasuk mekanisme penyelesaian sengketa tidak menimbulkan disharmonisasi antar peraturan.

\section{TINJAUAN PUSTAKA}

\section{Tinjauan tentang Usaha Pertambangan}

Merujuk pada pemahaman hukum pertambangan yang memberikan pengertian mengenai seperangkat aturan yang bertujuan untuk melindungi kepentingan yang berkaitan dengan industri pertambangan dan untuk meminimalkan konflik antara perusahaan tambang dan memberikan penjelasan yang bersifat umum kepada siapa saja yang mempunyai hak-hak untuk melakukan kegiatan pertambangan, 1 dapat diartikan bahwa hukum pertambangan memfokuskan kajian mengenai bahan tambang pada umumnya. Sedangkan bahan tambang itu sendiri meliputi mineral dan batubara, panas bumi, minyak dan gas bumi serta air tanah.

Merujuk pada pendapat Salim HS, bahwa hukum pertambangan dikelompokkan menjadi dua macam, yaitu :

1. Hukum pertambangan umum, mengkaji tentang panas bumi, minyak dan gas bumi, mineral radio aktif, mineral dan batubara, serta air tanah.

2. Hukum pertambangan khusus, hanya mengatur tentang pertambangan mineral dan batubara. ${ }^{2}$

Dengan demikian, kegiatan pertambangan dapat diklasifikasikan sebagai pertambangan umum yang melakukan penambangan panas bumi, minyak dan gas bumi, mineral dan radio aktif, mineral dan batubara, serta air tanah; dan pertambangan khusus yang melakukan penambangan mineral dan batubara.

\footnotetext{
${ }^{1}$ Salim HS,Hukum Pertambangan Mineral dan Batubara, ( Sinar Grafika : Jakarta, 2012), hlm. 12.

${ }^{2}$ Ibid, hlm. 14.
} 
Berdasarkan Pasal 1 angka (8) UndangUndang Nomor 4 Tahun 2009 tentang Pertambangan Mineral dan Batubara pengertian pertambangan adalah sebagian atau seluruh tahapan kegiatan dalam rangka penelitian, pengelolaan dan pengusahaan mineral atau batubara yang meliputi penyelidikan umum, eksplorasi, studi kelayakan, konstruksi, penambangan, pengolahan dan pemurnian, pengangkutan dan penjualan, serta kegiatan pascatambang.

Adapun pengertian usaha pertambangan berdasarkan Pasal 1 angka (5) Undang-Undang Nomor 4 Tahun 2009 tentang Pertambangan Mineral dan Batubara merupakan kegiatan dalam rangka pengusahaan mineral atau batubara. Kegiatan tersebut dilakukan untuk mengoptimalkan sumber daya alam tambang (bahan galian) yang terdapat di dalam bumi Indonesia.

Penggolongan usaha pertambangan berdasarkan Pasal 8 ayat (1) Undang-Undang Nomor 4 Tahun 2009 tentang Pertambangan Mineral dan Batubara meliputi :

1. pertambangan mineral radio aktif;

2. pertambangan mineral logam dan batubara; dan

3. pertambangan mineral bukan logam dan batuan.

Bahwa penggolongan usaha pertambangan ini diperlukan karena berkaitan dengan kewenangan pemberi izin dan pelaku usaha. Pelaksanaan usaha pertambangan dilakukan berdasarkan (1) Penugasan Usaha Pertambangan; (2) Izin Usaha Pertambangan; dan (3) Izin Pertambangan Rakyat.

Usaha pertambangan tidak hanya dilakukan oleh pemerintah semata-mata, tetapi dapat juga dilakukan oleh badan usaha maupun perorangan (Pasal 7 Undang-Undang Nomor 4 Tahun 2009 tentang Pertambangan Mineral dan Batubara). Untuk dapat menjalankan usaha pertambangan, badan usaha dan perorangan harus memenuhi persyaratan teknis, finansial, keahlian dan persyaratan administratif.

\section{Tinjauan tentang Wilayah Pertambangan dan Izin Pertambangan}

\section{Wilayah Pertambangan}

Pengelolaan dan pengusahaan pertambangan didasarkan pada penetapan wilayah pertambangan, yang merupakan bagian integral dari tata ruang nasional, sebagaimana tertuang dalam Pasal 1 angka (20) dan Pasal 9 UndangUndang Nomor 4 Tahun 2009 tentang Pertambangan Mineral dan Batubara. Dengan penetapan wilayah pertambangan, diharapkan dapat dilakukan perencanaan pengelolaan dan pengusahaan bahan galian yang diintegrasikan dengan perencanaan pembangunan secara menyeluruh termasuk aspek sosial ekonomi apabila kegiatan usaha pertambangan selesai dilakukan.
Sedangkan penetapan ruang lingkup wilayah pertambangan harus memperhatikan halhal sebagai berikut :

a. Penetapan suatu wilayah pertambangan harus dilakukan setelah berkoordinasi dengan DPR, pemerintah daerah, pendapat instansi terkait, dan masyarakat;

b. Dilakukan melalui proses yang transparan, partisipatif, dan bertanggung jawab; dan

c. Aspek sosial, budaya, ekonomi, ekologi, dan berwawasan lingkungan. ${ }^{3}$

Berdasarkan Pasal 13 Undang-Undang Nomor 4 Tahun 2009 tentang Pertambangan Mineral dan Batubara diatur mengenai jenis wilayah pertambangan sebagai berikut:

a. Wilayah Usaha Pertambangan
(WUP);
Wilayah Pertambangan Rakyat
(WPR); dan
c. Wilayah Pertambangan Negara.
(WPN).

Untuk menentukan wilayah pertambangan didasarkan pada suatu ukuran yang objektif dan didasarkan pada ukuran-ukuran atau kriteria ilmiah. Adapun kriteria tersebut meliputi (1) adanya indikasi formasi batuan pembawa mineral dan/atau pembawa batubara; (2) adanya potensi sumber daya bahan tambang yang berwujud padat dan/atau cair (Pasal 2 ayat (2) Peraturan Pemerintah Nomor 22 Tahun 2010 tentang Wilayah Pertambangan).

\section{Izin Pertambangan}

Dalam rangka bekerjanya hukum atau implementasi suatu peraturan maka diperlukan perangkat yang mendukung sifat memaksanya kaidah hukum, sehingga setiap orang harus melaksanakannya. Suatu peraturan yang dilaksanakan secara konsisten akan memberikan kewibawaan hukum dan memberikan kepastian hukum. ${ }^{4}$

Perangkat yang mampu mendukung bekerjanya hukum dan mampu mengendalikan perilaku orang atau badan usaha (pengusaha) yang sifatnya preventif adalah izin. Utrecht memberikan klasifikasi mengenai bentuk izin sebagai berikut :

a. Dispensasi, yaitu keputusan administrasi yang membebaskan suatu perbuatan dari kekuasaan suatu peraturan yang menolak perbuatan itu;

b. Izin, yaitu suatu keputusan administrasi negara yang memperkenankan suatu perbuatan yang pada umumnya dilarang, tetapi diperkenankan dan bersifat konkret;

c. Konsesi yaitu suatu perbuatan yang penting bagi umum, tetapi pihak swasta

\footnotetext{
3 Nandang Sudrajat, Teori dan Praktik Pertambangan Indonesia Menurut Hukum, (Pustaka Yustisia: Yogyakarta, 2010), hlm. 61.

${ }^{4}$ Ibid, hlm. 67.
} 
dapat turut serta dengan syarat pemerintah turut campur. ${ }^{5}$

Mengutip hasil karya ilmiah dalam tesisnya, Jaja Ahmad memberi pemahaman bahwa dengan perizinan ada sesuatu yang akan dituju, yaitu :

a. Keinginan mengarahkan aktivitas tertentu;

b. Mencegah bahaya yang mungkin timbul, sebagai contoh dalam izin lingkungan, izin dapat mencegah pembuangan limbah yang berlebih;

c. Untuk melindungi objek-objek tertentu, seperti cagar budaya;

d. Membagi benda-benda yang jumlahnya terbatas;

e. Mengarahkan orang-orang tertentu yang akan melakukan aktivitas. ${ }^{6}$

Izin tersebut ditetapkan oleh pejabat negara, dengan demikian dilihat dari penetapannya, maka izin merupakan instrumen pengendali dan alat pemerintah untuk mencapai apa yang menjadi sasarannya.

Mencermati uraian tersebut, dapat diketahui bahwa izin merupakan legalitas bagi perseorangan, kelompok, atau badan usaha yang dikeluarkan oleh pejabat negara untuk melakukan kegiatan atau aktivitas tertentu dengan keharusan melaksanakan kewajiban-kewajiban sesuai yang ditetapkan dalam izin dimaksud. Apabila dalam pelaksanaannya penerima izin tidak menjalankan kewajiban, maka pemberi izin berwenang menjatuhkan sanksi.

Sehubungan dengan usaha pertambangan, untuk memperoleh legalitas kegiatan usaha pertambangan berdasarkan Undang-Undang Nomor 4 Tahun 2009 dilakukan dalam bentuk izin usaha yang meliputi izin pertambangan rakyat, izin usaha pertambangan, izin usaha pertambangan khusus. Berbeda dengan pengaturan dalam UndangUndang Nomor 11 Tahun 1967 terdiri dari berbagai macam bentuk yaitu Kontrak Pertambangan, Kontrak Karya, PKP2B (Perjanjian Karya Pengusahaan Pertambangan Batubara) untuk pertambangan batubara, SIPD (Surat Izin Pertambangan Daerah) untuk bahan galian industri, dan izin pertambangan rakyat untuk tambang rakyat.

Pada prakteknya kontrak atau izin pengelolaan pertambangan di Indonesia saat ini masih beraneka ragam, karena masih berlakunya berbagai jenis kontrak atau izin yang ditetapkan sebelum berlakunya Undang-Undang Nomor 4

${ }^{5}$ Utrecht, Pengantar Hukum Administrasi Negara Indonesia

6 Jaja Ahmad Jayus, Lembaga Perizinan Sebagai Sarana Pengendalian Investasi dalam Implementasi Otonomi Daerah, Tesis, Program Pasca Sarjana Ilmu Hukum, UNPAR, Bandung, 2001, hlm. 104.
Tahun 2009 tentang Pertambangan Mineral dan Batubara. Apabila dicermati, walaupun UndangUndang Nomor 4 Tahun 2009 tentang Pertambangan Mineral dan Batubara sudah diundangkan sejak tahun 2009 namun dasar legalitas kegiatan usaha pertambangan yang berlaku kini masih beragam, yaitu :

a. Kontrak karya;

b. Perjanjian karya pengusahaan pertambangan batubara;

c. Kuasa pertambangan;

d. Izin Pertambangan Rakyat;

e. Izin Usaha Pertambangan;

f. Izin Usaha Pertambangan Khusus.

\section{Tinjauan tentang Penyelesaian Sengketa dan} Sengketa Pertambangan

\section{Penyel esaian Sengketa}

Penyelesaian sengketa yang sifatnya efektif merupakan idaman setiap pihak yang terlibat dalam suatu kegiatan bisnis. Oleh karena itu pihak-pihak yang bersengketa selalu berusaha mencari cara penyelesaian sengketa dalam rangka untuk selalu mencapai posisi keseimbangan dan agar tetap dapat bertahan. Pada dasarnya ada tiga cara penyelesaian sengketa, yang diuraikan sebagai berikut :

a. Penyelesaian sengketa melalui pengadilan, yaitu suatu pola penyelesaian sengketa yang terjadi antara pihak yang bersengketa, di mana dalam penyelesaian sengketa itu diselesaikan oleh pengadilan dan putusannya bersifat mengikat.

b. Penyelesaian sengketa melalui ADR (Alternative Dispute Resolution) atau alternatif penyelesaian sengketa (APS), yaitu sekumpulan prosedur atau mekanisme yang berfungsi memberi alternatif atau pilihan suatu cara penyelesaian sengketa melalui bentuk APS/arbitrase agar memperoleh putusan akhir dan mengikat para pihak. ${ }^{7}$

c. Penyelesaian sengketa melalui lembaga adat, merupakan penyelesaian sengketa yang menggunakan institusi yang hidup dan berkembang dalam masyarakat hukum adat.

Adapun sumber-sumber hukum yang menjadi dasar untuk penyelesaian sengketa adalah sebagai berikut :

1) Ketentuan-ketentuan Hukum Internasional, yang terbagi atas 3 jenis yaitu Perjanjian Bilateral, Perjanjian Multilateral dan Perjanjian Regional;

2) Ketentuan-ketentuan Hukum Nasional, meliputi Undang-Undang Nomor 25 Tahun

${ }^{7}$ H. Priyatna Abdurrasyid, Arbitrase \& Alternatif Penyelesaian Sengketa Suatu Pengantar, (Jakarta : PT Fikahati Aneska bekerjasama dengan Badan Arbitrase Nasional, 2002), hlm. 42. 
2007 tentang Penanaman Modal; UndangUndang Nomor 30 Tahun 1999 tentang Arbitrase dan Alternatif Penyelesaian Sengketa; Undang-Undang Nomor 7 Tahun 1994 tentang Pengesahan WTO Agreement 1994, termasuk Annexnya yang berkaitan dengan tata cara penyelesaian sengketa;

3) Kontrak Karya Pertambangan, Perjanjian Karya Pengusahaan Pertambangan Batubara (PKP2B), yang juga mengatur mekanisme penyelesaian sengketa antara kontraktor (investor) dengan pemerintah;

4) Kuasa Pertambangan, karena tidak bersifat kontraktual maka tidak ditemui ketentuan mengenai mekanisme khusus untuk penyelesaian sengketa yang berkaitan dengan pemberian kuasa pertambangan.

\section{Sengketa Pertambangan}

Penggunaan istilah sengketa itu sendiri belum ada kesatuan pandangan dari para ahli. Ada ahli yang menggunakan istilah sengketa, dan ada juga yang menggunakan istilah konflik.

a. Richard L. Abel mengartikan sengketa (dispute) adalah :

"pernyataan publik mengenai tuntutan yang tidak selaras (inconsistent claim) terhadap sesuatu yang bernilai". 8

b. Dean G. Pruitt dan Jeffrey Z. Rubin mengemukakan pengertian konflik sebagai berikut :

"Konflik adalah persepsi mengenai perbedaan kepentingan (perceived divergence of interest), atau suatu kepercayaan bahwa aspirasi pihak-pihak yang berkonflik tidak dicapai secara simultan (secara serentak)". 9

Dari pendapat para ahli tersebut dapat dirumuskan bahwa sengketa merupakan pertentangan, perselisihan atau percekcokan yang terjadi antara pihak yang satu dengan pihak lainnya dan atau antara pihak yang satu dengan berbagai pihak yang berkaitan dengan sesuatu yang bernilai, baik itu berupa uang maupun benda. 10

Sengketa pertambangan bersumber dari masalah-masalah yang timbul dengan adanya kegiatan pertambangan yang meliputi penyelidikan umum, eksplorasi dan eksploitasi bahan tambang dan berakibat menimbulkan konflik. Dengan demikian yang dimaksud sengketa pertambangan

\footnotetext{
${ }^{8}$ Lawrence M. Friedman, American Law an Introduction (Hukum Amerika : Sebuah Pengantar), Penerjemah : Wisnu Basuki, (Jakarta : Tata Nusa, 2001) hlm. 11.

${ }^{9}$ Dean G. Pruitt dan Jeffrey Z. Rubin, Konflik Sosial, (Yogyakarta : Pustaka Pelajar, 2004), hlm. 9-10.

${ }^{10} \mathrm{H}$ Salim HS., Hukum Penyelesaian Sengketa Pertambangan di Indonesia, (Bandung : Pustaka Reka Cipta, 2013), hlm. 221.
}

adalah sengketa yang terjadi dalam pelaksanaan kegiatan pertambangan.

Keberadaan perusahaan tambang sering kali menimbulkan konflik dengan masyarakat sekitar kegiatan penambangan, karena tidak ditaatinya kebijakan yang dikeluarkan oleh pemerintah. Menurut Salim HS, jenis sengketa yang terjadi dalam pelaksanaan kegiatan pertambangan adalah :

a. Sengketa antara indigeneos people dengan perusahaan tambang;

b. Sengketa pencemaran lingkungan;

c. Sengketa hak atas tanah;

d. Sengketa divestasi saham;

e. Sengketa program community development;

f. Sengketa wilayah kontrak karya; dan

g. Sengketa perburuhan. 11

\section{METODE PENELITIAN}

\section{Metode Pendekatan}

Metode pendekatan yang akan digunakan dalam penelitian ini adalah pendekatan yuridis normatif. Pendekatan ini dipilih mengingat dalam rangka mencapai tujuan penelitian/ target penelitian peneliti mengacu kepada norma-norma hukum yang terdapat dalam peraturan perundangundangan, putusan-putusan pengadilan serta norma-norma hukum yang ada dalam masyarakat dan instrumen Hukum Pertambangan. 12 Pendekatan penelitian terhadap peraturan perundang-undangan dilakukan dengan menelaah semua peraturan perundang-undangan dan regulasi yang berhubungan dengan isu hukum yang akan diteliti yaitu kajian normatif terhadap pengaturan kegiatan usaha pertambangan dalam kaitannya dengan penyelesaian sengketa pertambangan.

\section{Spesifikasi Penelitian}

Pada penelitian ini dilakukan secara deskriptif analitis, yaitu dengan memberikan gambaran secara khusus berdasarkan pada fakta yang ada. Berkaitan dengan hal tersebut, penelitian ini bermaksud memaparkan kajian normatif terhadap pengaturan kegiatan usaha pertambangan dalam kaitannya dengan penyelesaian sengketa pertambangan yaitu dengan mendiskripsikan dan mengintepretasikan.

\section{Jenis Data dan Sumber Data}

Dalam penelitian ini, data yang digunakan adalah data sekunder yang diperoleh dari penelitian kepustakaan. Data sekunder dalam penelitian ini dibedakan menjadi 3 (tiga), yaitu :

a. Bahan hukum primer, adalah produk hukum yang mengikat warga negara. Dalam penelitian ini digunakan sumber-sumber yang meliputi :

1) Indische Mijnwet 1899;

\footnotetext{
${ }^{11} \mathrm{H}$ Salim HS, Ibid, hlm. 215.

${ }^{12}$ Ali, Zainudin, Metode Penelitian Hukum, (Jakarta : Sinar Grafika, 2010), hlm. 105.
} 
2) Undang-Undang Nomor 37 Prp. Tahun 1960 tentang Pertambangan;

3) UU No. 11 Tahun 1967 tentang Ketentuan-Ketentuan Pokok Pertambangan;

4) UU No. 30 Tahun 1999 tentang Arbitrase dan Alternatif Penyelesaian Sengketa;

5) UU No. 4 Tahun 2009 tentang Pertambangan Mineral dan Batubara;

6) UU No. 32 Tahun 2009 tentang Perlindungan dan Pengelolaan Lingkungan Hidup;

7) Peraturan Pemerintah Nomor 22 Tahun 2010 tentang Wilayah Pertambangan.

8) Peraturan Pemerintah Nomor 02 Tahun 2013 tentang Pengawasan Terhadap Penyelenggaraan Pengelolaan Usaha Pertambangan yang Dilaksanakan oleh Pemerintah Provinsi dan Pemerintah Kabupaten/ Kota.

b. Bahan Hukum sekunder, adalah bahan-bahan hukum yang erat kaitannya dengan bahan hukum primer. Dalam penelitian ini digunakan sumber-sumber ilmiah yang meliputi :

1) Buku-buku ilmiah yang membahas pertambangan dan penyelesaian sengketa pertambangan.

2) Hasil-hasil penelitian yang berkaitan dengan penelitian.

3) Berbagai makalah, hasil, majalah, jurnal ilmiah yang berkaitan dengan penelitian.

4) Keputusan pengadilan yang berkaitan dengan penelitian.

c. Bahan hukum tersier, adalah bahan hukum yang memberikan informasi mengenai bahan hukum primer maupun bahan hukum sekunder yang meliputi Kamus Hukum, Kamus Istilah Ekonomi dan kamus lain yang dapat menunjang penelitian ini.

\section{Analisis Data}

Data hasil penelitian yang berupa data sekunder, dianalisis secara kualitatif. Analisis kualitatif ini dimaksudkan untuk mengemukakan hasil penelitian dan hasil sinkronisasi yang diuraikan dalam bentuk rumusan-rumusan dan uraian-uraian. Untuk kemudian dilakukan editing data, penyajian data dan pengambilan simpulan.

\section{HASIL PENELITIAN DAN}

\section{PEMBAHASAN}

Perkembangan Pengaturan Kegiatan Usaha Bidang Pertambangan di Indonesia.

\section{Hak Menguasai Negara Bidang Pertambangan}

Salah satu tujuan pembentukan negara Indonesia berdasar Pembukaan Undang-Undang Dasar Negara Republik Indonesia Tahun 1945 adalah untuk memajukan kesejahteraan umum. Atas dasar tujuan tersebut, kemudian para pendiri negara merasa perlu untuk merumuskan ketentuan yang mengatur keberadaan sumber daya alam yang terdapat di wilayah yurisdiksi Indonesia dalam konteks kehidupan berbangsa dan bernegara. Untuk itu, ketentuan yang mengatur sumber daya alam kemudian dirumuskan dalam Pasal 33 ayat (3) Undang-Undang Dasar Negara Republik Indonesia Tahun 1945, yang menegaskan bahwa : "Bumi dan air dan kekayaan alam yang terkandung di dalamnya dikuasai oleh negara dan dipergunakan untuk sebesar-besarnya kemakmuran rakyat".

Dari pengertian "dikuasai oleh negara" tersebut, tidak ditemui penjelasan resmi, namun satu hal yang disepakati bahwa dikuasai oleh negara tidak sama dengan yang dimiliki oleh negara. Kesepakatan ini bertalian dengan suatu bentuk reaksi dari sistem atau konsep domein yang dipergunakan pada masa kolonial Hindia Belanda, yang dikenal dengan asas domein dan mengandung pengertian mengenai kepemilikan (ownership). Bahwa negara adalah pemilik atas tanah, oleh karena itu mempunyai segala wewenang melakukan tindakan yang bersifat kepemilikan (eigensdaad). ${ }^{13}$

Untuk memberikan makna atau penjelasan mengenai penguasaan negara yang berkaitan dengan sumber daya alam khususnya pertambangan, memang tidaklah mudah, mengingat kegiatan pertambangan disatu sisi berhubungan dengan kepentingan investasi yang lebih mengutamakan keuntungan ekonomi semata dan disisi lain mengkait dengan penguasaan negara adalah lebih mengutamakan kepentingan dan kemakmuran rakyat. Namun yang lebih penting disini adalah dengan dirumuskannya penguasaan oleh negara untuk sumber daya alam khususnya pertambangan harusnya digunakan sebagai instrumen hukum yang memberikan kepastian adanya faktor kendali negara terhadap pengelolaan di bidang pertambangan.

Rumusan hak menguasai negara yang lebih mencerminkan kedaulatan negara atas penguasaan sumber daya alam, dalam hal ini adalah bahanbahan tambang, minimal harus memenuhi unsurunsur sebagai berikut :

a. unsur pengendalian negara terhadap arah, kebijakan dan peruntukan atau pemanfaatan bahan-bahan tambang, khususnya bahan tambang yang menyangkut hajat hidup orang banyak dalam rangka menjaga stabilitas pertahanan, keamanan, dan ekonomi nasional.

b.unsur pengaturan negara, dalam konteks ini negara memberikan aturan secara limitatif, yaitu meliputi hak pendelegasian

${ }^{13}$ Ibid, hlm. 230-231. 
pengelolaan terhadap pihak ketiga, hak pengaturan alokasi peruntukan bahan tambang dalam rangka mendukung sektor industri strategis yang harus didistribusikan secara adil dan proporsional bagi daerah penghasil, pemerintah dan daerah lainnya.

c.unsur otoritas negara yang memberi kewenangan kepada negara untuk mengambil hasil dan manfaat atas kegiatan pertambangan secara ekonomis untuk kepentingan rakyat yang berupa royalti, pajak, retribusi dan hak atas kepemilikan saham secara otomatis.

d.unsur perlindungan negara yang memberikan kewajiban kepada negara untuk melakukan pengawasan atas pelaksanaan operasional penambangan, khususnya pengawasan dan pengendalian dalam aspek sistem penambangan yang baik dan benar, dengan mengedepankan pada asas manfaat jangka panjang dan daya dukung lingkungan demi kepentingan pembangunan berkelanjutan. 14

\section{Perkembangan Pengaturan Kegiatan Usaha Bidang Pertambangan di Indonesia.}

Pengaturan pengelolaan bidang

pertambangan di Indonesia, sama halnya dengan landasan hukum bidang lain pada umumnya, yaitu dimulai sejak pemerintahan Hindia Belanda. Sampai dengan pemerintahan Orde Lama, pengaturan pengelolaan bidang pertambangan masih menggunakan produk hukum Hindia Belanda yang langsung diadopsi menjadi hukum pertambangan Indonesia. Adapun perkembangan pengaturan di bidang pertambangan adalah sebagai berikut :

\section{A. Berlakunya Indische Mijnwet 1899(IM 1899)}

Pengaturan pengelolaan bidang pertambangan pada masa pemerintahan Hindia Belanda diatur berdasarkan peraturan yang disebut Indische Mijnwet (Mining act of the Indies) 1899 (IM 1899). Salah satu ketentuan yang terdapat dalam Indische Mijnwet 1899 (IM 1899), adalah mengatur tentang ketentuan kontrak antara pemerintah Hindia Belanda dengan pihak swasta. Ketentuan kontrak tersebut dikenal dengan nama 5 A Contract. Pasal tersebut, merupakan cikal bakal lahirnya ketentuan kontrak karya atau kontrak bagi hasil yang diberlakukan setelah kemerdekaan.

Dalam Indische Mijnwet 1899 (IM 1899) tersebut, diketahui adanya ketentuan-ketentuan mengenai kegiatan pertambangan, yaitu :

a.pengelolaan mineral dikontrol oleh izin yang dikeluarkan oleh Biro Pertambangan atau Pemerintah Provinsi;

${ }^{14}$ Nandang Sudrajat, ibid, hlm. 23-24. b.konsesi pertambangan diberikan berdasarkan permohonan yang diajukan kepada Gubernur Jenderal;

c.izin untuk perolehan konsesi hanya dapat diberikan kepada orang Belanda (dutch subjects), penduduk Hindia Belanda, dan perusahaan yang terdaftar di negeri Belanda atau di Hindia Belanda;

d.terdapat pengaturan mengenai kewajiban pembayaran (iuran) tahunan dan kewajiban-kewajiban lainnya seperti pajak. Terdapat pula pengaturan mengenai royalti dari pemilik konsesi pertambangan. Disamping itu, terdapat ketentuan yang berasal dari beberapa peraturan-peraturan pelaksanaan yang terkait dengan perlindungan terhadap hak negara dan pengembangan industri pertambangan yang diperbolehkan oleh pemerintah Hindia Belanda.

B. Berlakunya Undang-Undang Nomor 37 Prp. Tahun 1960 tentang Pertambangan

Setelah kemerdekaan, para pemimpin kemudian melakukan perumusan tentang pengaturan tata cara pengelolaan bidang pertambangan yang merupakan perwujudan sebagai negara merdeka dan berdaulat. Setelah melalui perdebatan yang cukup panjang, kemudian ditetapkan peraturan pengelolaan bidang pertambangan dengan diterbitkannya Peraturan Pemerintah Pengganti Undang-Undang (Perpu) Nomor 37 Tahun 1960 yang mengatur khusus bidang Pertambangan. Setelah diterbitkannya Peraturan Pemerintah Pengganti Undang-Undang (Perpu) Nomor 37 Tahun 1960, kemudian pemerintah Republik Indonesia menerbitkan pula Peraturan Pemerintah Pengganti Undang-Undang (Perpu) Nomor 44 Tahun 1960 yang mengatur khusus tentang Minyak dan Gas Bumi.

Peraturan Pemerintah Pengganti UndangUndang (Perpu) Nomor 37 Tahun 1960 pada dasarnya merupakan Indische Mijnwet 1899 (IM 1899) dalam versi Indonesia. Artinya, ketentuanketentuan yang termuat dalam Peraturan Pemerintah Pengganti Undang-Undang (Perpu) Nomor 37 Tahun 1960 merupakan adopsi dari ketentuan-ketentuan dalam Indische Mijnwet 1899 (IM 1899) dengan hanya mengganti otoritasnya saja, misalnya : setiap kata Ratu dan Gubernur Jenderal dalam Indische Mijnwet 1899 (IM 1899), masing-masing diganti menjadi milik nasional dan pemerintah saja pada Perpu. ${ }^{15}$

\footnotetext{
${ }^{15}$ Bambang Yunianto, Rochman Saefudin dan Ijang Suherman, "Kebijakan Sektor Energi dan Sumber Daya Mineral dan Implikasinya Terhadap Pertambangan Emas, dalam Penambangan dan Pengolahan Emas di Indonesia", Puslitbang Teknologi Mineral dan Batu Bara, Bandung, 2004, hlm. 19.
} 
Dalam perkembangannya, Peraturan Pemerintah Pengganti Undang-Undang (Perpu) Nomor 37 Tahun 1960 kemudian menjadi UndangUndang Nomor 37 Prp. Tahun 1960 tentang Pertambangan, yang merupakan produk nasional pertama regulasi di bidang pertambangan. Undangundang Pertambangan Tahun 1960 tersebut mengizinkan pemerintah menarik modal asing untuk mengembangkan kegiatan eksplorasi dan eksploitasi dalam usaha pertambangan di Indonesia.

Dalam Undang-Undang Nomor 37 Prp. Tahun 1960 tersebut kembali diadopsi prinsip kedaulatan negara atas sumber daya alam sebagaimana yang terdapat pada peraturan perundang-undangan dimasa kolonialisme. Hal tersebut tercermin dalam Pasal 2 ayat (1) UndangUndang Nomor 37 Prp. Tahun 1960, yaitu :

"Segala bahan galian yang berada di dalam, di atas dan di bawah permukaan bumi, dalam wilayah hukum pertambangan Indonesia yang merupakan letakan-letakan atau timbunan-timbunan alam adalah kekayaan nasioal dan dikuasai oleh negara".

Beberapa hal pokok yang diatur dalam Peraturan Pemerintah Pengganti Undang-Undang tersebut antara lain meliputi :

a. Dalam Undang-Undang Nomor 37 Prp. Tahun 1960, ditiadakan sistem konsesi sebagaimana yang ada dalam Indische Mijnwet 1899. Adapun yang menjadi otoritas dalam kegiatan usaha pertambangan adalah negara (melalui Perusahaan Negara) dan atau daerah (melalui Perusahaan Daerah).

b. Pelaksanaan kegiatan usaha pertambangan yang dilakukan oleh Perusahaan Negara atau oleh Perusahaan Negara bersama-sama Perusahaan Daerah adalah untuk bahan galian strategis. Kemudian pelaksanaan kegiatan pertambangan bahan galian vital dilakukan oleh Perusahaan Negara atau Perusahaan Daerah, serta dilakukan oleh badan atau perorangan swasta yang melakukan usaha bersama dengan Perusahaan Negara atau Perusahaan Daerah. Badan usaha tersebut harus berbadan hukum Indonesia dengan syarat-syarat yang sudah ditentukan. Untuk bahan galian yang bukan termasuk bahan galian strategis dan bahan galian vital diatur oleh Pemerintah Daerah Tingkat I (Pemerintah Provinsi). Berdasarkan ketentuan tersebut, maka perusahaan asing tidak dapat secara langsung melakukan kegiatan usaha pertambangan di Indonesia, bahkan untuk bahan galian non-strategis dan atau bahan galian non-vital sekalipun. c. Pengusahaan pertambangan terhadap bahan galian strategis dan vital hanya dapat dilakukan setelah memperoleh Kuasa Pertambangan.

d. Pendapatan negara melalui Undang-Undang Nomor 37 Prp. Tahun 1960 didapat dari pungutan-pungutan terhadap iuran pasti, iuran eksplorasi dan/atau eksploitasi dan/atau pembayaran-pembayaran lainnya yang berhubungan dengan pemberian kuasa pertambangan yang bersangkutan.

e. Belum terdapat pengaturan mengenai Kontrak Karya (Contract of Work), namun dalam Undang-Undang Nomor 44 Prp. Tahun 1960 tentang Pertambangan Minyak dan Gas Bumi telah mengaturnya.

Pada dasarnya prinsip kedaulatan negara yang diadopsi dalam Undang-Undang Nomor 37 Prp. Tahun 1960 sama dengan apa yang ada pada Indische Mijnwet 1899. Namun terdapat perubahan yang signifikan antara lain, mengenai perubahan dari sistem konsesi ke sistem pengusahaan pertambangan yang mana kegiatan usaha pertambangan dilakukan oleh negara atau daerah. Apabila suatu badan usaha swasta akan melakukan kegiatan usaha pertambangan, maka dilakukan melalui usaha bersama negara atau daerah.

\section{Berlakunya Undang-Undang Nomor 11 Tahun 1967 tentang Ketentuan-Ketentuan Pokok Pertambangan}

Dalam perkembangan selanjutnya seiring dengan perkembangan politik dan bergantinya rezim pemerintahan, juga mengakibatkan perubahan terhadap perundang-undangan di bidang pertambangan. Setelah berlakunya Undang-Undang Nomor 37 Prp. Tahun 1960 pada masa pemerintahan Presiden Soekarno (orde lama), kemudian diterbitkan Undang-Undang Nomor 11 Tahun 1967 tentang Ketentuan-Ketentuan Pokok Pertambangan yang ditandatangi oleh Presiden Soeharto di Jakarta pada 2 Desember 1967.

Beberapa hal pokok yang diatur dalam Undang-Undang Nomor 11 Tahun 1967 tersebut antara lain meliputi :

a. Bahwa negara menguasai segala bahan galian (sumberdaya mineral dan batubara) yang ada dalam wilayah hukum pertambangan Indonesia;

b. Terdapat penggolongan bahan galian, yaitu bahan galian strategis, bahan galian vital, bahan galian non strategis dan non vital;

c. Pelaksanaan pertambangan bahan galian strategis dilaksanakan oleh instansi pemerintah yang ditunjuk oleh menteri atau perusahaan negara. Disamping itu, usaha swasta yang telah memenuhi syarat sebagai badan hukum Indonesia dapat melaksanakan pertambangan bahan galian strategis dengan pertimbangan bahwa dari sisi ekonomi akan lebih menguntungkan. Apabila jumlahnya 
sangat kecil, maka pengusahaan pertambangan dapat dilakukan melalui pertambangan rakyat.

d. Pelaksanaan pertambangan juga dapat dilakukan kepada pihak lain sebagai kontraktor (kontrak karya).

e. Apabila bahan galian yang dijadikan objek dalam pelaksanaan pertambangan adalah bahan galian strategis dan berbentuk penanaman modal asing, maka kontrak karya yang dilakukan pemerintah baru berlaku setelah mendapat persetujuan DPR.

f. Usaha pertambangan dapat dilakukan oleh pelaksana pertambangan setelah mendapat Kuasa Pertambangan, kecuali untuk kontrak karya/ perjanjian karya. Kuasa Pertambangan dapat diberikan dalam bentuk

1) Surat Keputusan Penugasan Pertambangan (diberikan kepada instansi pemerintah yang meliputi penyelidikan umum dan eksplorasi).

2) Surat Keputusan Izin Pertambangan Rakyat (diberikan kepada rakyat setempat untuk melakukan kegiatan usaha pertambangan secara kecilkecilan).

3) Surat Keputusan Kuasa Pertambangan (diberikan kepada Perusahaan Negara, Perusahaan Daerah, Badan Usaha Swasta untuk melakukan kegiatan usaha pertambangan sebagimana disebutkan dalam Pasal 14 UndangUndang Nomor 11 Tahun 1967.

g. Pendapatan negara diperoleh dari iuran tetap, iuran eksplorasi dan/atau eksploitasi dan/atau pembayaran-pembayaran lain yang berhubungan dengan kuasa pertambangan yang bersangkutan. Dalam hal perjanjian karya/ kontrak karya maka yang wajib membayar adalah kontraktor.

h. Pengaturan tentang penyelesaian sengketa, dapat diselesaikan salah satunya di forum International Center for Settlement of Disputes (ICSID), namun apabila ICSID tidak dapat menyelesaikan maka sengketa dapat dibawa ke badan arbitrase yang lain.

i. Khusus mengenai kontrak karya pada pengusahaan pertambangan batubara, diatur dalam Peraturan Pemerintah Nomor 75 Tahun 1996 tentang Ketentuan Pokok Perjanjian Karya Pengusahaan Pertambangan Mineral dan Batubara (PKP2B).

j. Terjadi perubahan yang cukup signifikan dari substansi dalam Undang-Undang Nomor 37 Prp. Tahun 1960 pada Undang-Undang Nomor 11 Tahun 1967 yaitu mengenai masuknya investasi asing ke Indonesia dan adanya pengaturan mengenai kontrak karya yang terkait juga dengan Undang-Undang Nomor 1 Tahun 1967 tentang Penanaman Modal Asing.

\section{Berlakunya Undang-Undang Nomor 4 Tahun 2009 tentang Pertambangan Mineral dan Batubara}

Lebih lanjut, pada akhir tahun 2008 pemerintah mengesahkan Undang-Undang Nomor 4 Tahun 2009 tentang Pertambangan Mineral dan Batubara (UU Minerba). Undang-undang tersebut dengan jelas mengatur mengenai pertambangan mineral dan batubara, hal tersebut tertuang dalam Pasal 34 ayat (1) yang menyatakan bahwa usaha pertambangan terdiri dari pertambangan mineral dan pertambangan batubara.

Beberapa hal pokok yang diatur dalam Undang-Undang Nomor 4 Tahun 2009 tersebut antara lain meliputi :

a. Izin Usaha Pertambangan.

Pasca diundangkannya Undang-Undang Nomor 4 Tahun 2009, salah satu implikasi yang cukup signifikan pengaruhnya adalah adanya penyatuan dalam perolehan hak atas kegiatan usaha pertambangan dalam satu atap, dan terbagi dalam 3 (tiga) ruangan yaitu Izin Usaha Pertambangan (IUP), Izin Pertambangan Rakyat (IPR), dan Izin Usaha Pertambangan Khusus (IUPK). Dengan demikian maka sistem perolehan dalam regulasi yang sebelumnya, antara lain Sistem Konsesi, Kuasa Pertambangan (KP), Pengusahaan Pertambangan Mineral dan Batubara (PKP2B), dan Kontrak Karya (KK) tidak berlaku lagi kecuali yang diatur dalam ketentuan peralihan Undang-Undang Nomor 4 Tahun 2009.

b. Investasi Asing.

Indonesia telah menjadi anggota World Trade Organization (WTO). Implikasi dari fakta tersebut adalah kran investasi asing harus dibuka "sederas" mungkin. Undang-Undang Nomor 4 Tahun 2009 mengakomodasi adanya fakta tersebut dalam beberapa ketentuannya, antara lain mengenai keringanan dan fasilitas perpajakan yang diberikan pemerintah.

c. Penerimaan Negara dan Daerah.

Dalam Undang-Undang Nomor 4 Tahun 2009, pengaturan mengenai penerimaan negara dan daerah dibagi menjadi 2 (dua) yaitu penerimaan pajak dan penerimaan bukan pajak. Dengan demikian pengaturan penerimaan negara dan daerah lebih tegas dibanding undang-undang di bidang pertambangan sebelumnya.

d. Penyelesaian Sengketa di Bidang Pertambangan. 
Dalam Undang-Undang Nomor 4 Tahun 2009, lebih diperjelas mengenai forum penyelesaian sengketa di bidang pertambangan, yaitu dengan adanya pengaturan mengenai penyelesaian sengketa yang harus dilakukan di Indonesia, baik melalui arbitrase maupun pengadilan.

Lebih lanjut dapat dikemukakan perbandingan pengaturan kegiatan usaha di bidang pertambangan mulai dari rezim pemerintahan Belanda sampai dengan pengaturan berdasarkan UU Nomor 4 Tahun 2009 sebagaimana Tabel - 1 berikut :

\section{Mekanisme Penyelesaian Sengketa Bidang Pertambangan Dalam Rangka Menciptakan Kepastian Hukum dan Keadilan.}

Dalam pelaksanaan kegiatan tambang, kontraktor yang ditunjuk atau pemegang IPR, IUP,IUPK sering menimbulkan masalah yang pada akhirnya menimbulkan sengketa diantara para pihak, dan dimungkinkan juga timbul sengketa dengan masyarakat di wilayah kegiatan pertambangan.

Dalam upaya penyelesaian sengketa, pada prinsipnya menjadi hak para pihak untuk memilih mekanisme apa yang akan digunakan terutama yang didasarkan pada kontrak karya, PKP2B atau kontrak pertambangan, sedangkan yang didasarkan atas perizinan mekanisme yang digunakan adalah sesuai dengan Undang-Undang Nomor 4 Tahun 2009 tentang Pertambangan Mineral dan Batubara.

A. Penyelesaian Sengketa Pertambangan

Berdasarkan Undang-Undang Nomor 11

Tahun 1967 tentang Ketentuan-Ketentuan Pokok Pertambangan.

Mengingat saat ini masih ditemui pengaturan usaha pertambangan berdasarkan Undang-Undang Nomor 11 Tahun 1967 tentang Ketentuan-Ketentuan Pokok Pertambangan yaitu Kontrak Pertambangan, Kontrak Karya, PKP2B, sebagaimana dirumuskan dalam Pasal 169 UndangUndang Nomor 4 Tahun 2009 tentang Pertambangan Mineral dan Batubara maka dalam penyelesaian sengketa pertambangan juga masih menggunakan mekanisme sebagaimana yang telah disepakati oleh para pihak. Dari berbagai mekanisme yang tersedia secara keseluruhan dapat dibagi dalam dua cara yaitu proses non adjudikasi dan proses adjudikasi yang diuraikan sebagai berikut :

1. Proses Non Adjudikasi, meliputi negosiasi, mediasi, konsiliasi;

2. Proses Adjudikasi

a. Litigasi

b. Arbitrase

1) Mahkamah arbitrase permanen merupakan salah satu institusi yang dijadikan media untuk penyelesaian sengketa antar negara secara damai, yang dalam perkembangannya bahwa arbitrase dapat juga digunakan untuk penyelesaian sengketa antara negara dengan subjek hukum bukan negara dengan mengikuti pola UNCITRAL Rules of Arbitration;

2) Terhadap sengketa yang terjadi antara negara tuan rumah dengan investor asing, mekanisme arbitrase yang ditempuh berpedoman pada ketentuan ICSID Convention.

3) Terhadap sengketa antar investor, pilihan mekanisme penyelesaian sengketa melalui arbitrase tergantung pada para pihak dalam perjanjian. Terdapat dua bentuk arbitrase yang dapat dipilih yaitu Arbitrase asing dan Arbitrase nasional.

Berdasarkan Pasal 32 Undang-Undang Nomor 25 Tahun 2007 tentang Penanaman Modal, secara umum cara penyelesaian sengketa yang dapat ditempuh apabila timbul sengketa adalah sebagai berikut :

1. Penyelesaian sengketa melalui musyawarah;

2. Melalui arbitrase atau alternatif penyelesaian sengketa atau pengadilan sesuai dengan ketentuan peraturan perundang-undangan;

3. Sengketa antara pemerintah dengan investor dalam negeri diselesaikan melalui arbitrase berdasarkan kesepakatan para pihak, sedangkan apabila penyelesaian sengketa melalui arbitrase tidak disepakati, penyelesaian sengketa tersebut akan diselesaikan melalui pengadilan;

4. Sengketa antara pemerintah dengan investor asing akan diselesaikan melalui arbitrase internasional yang harus disepakati oleh para pihak. 
Tabel - 1

Perbandingan Pengaturan Bidang Pertambangan Sejak IM 1899 Sampai Dengan UU Nomor 4 Tahun 2009

\begin{tabular}{|c|c|c|c|c|c|}
\hline $\begin{array}{l}\text { N } \\
\text { o. }\end{array}$ & $\begin{array}{l}\text { Materi } \\
\text { Pokok }\end{array}$ & $\begin{array}{c}\text { IM } \\
1899\end{array}$ & $\begin{array}{c}\text { UU No. } \\
37 \text { Prp. } \\
\text { Tahun } \\
1960\end{array}$ & $\begin{array}{c}\text { UU No. } 11 \\
\text { Tahun } 1967\end{array}$ & $\begin{array}{c}\text { UU No. } 4 \text { Tahun } \\
2009\end{array}$ \\
\hline 1 & Judul & $\begin{array}{l}\text { Indische } \\
\text { Mijnwet }\end{array}$ & $\begin{array}{l}\text { Pertam } \\
\text { bangan }\end{array}$ & $\begin{array}{l}\text { Ketentuan- } \\
\text { ketentuan } \\
\text { Pokok } \\
\text { Pertambangan }\end{array}$ & $\begin{array}{ll}\text { Pertambangan } \\
\text { Mineral dan } \\
\text { Batubara }\end{array}$ \\
\hline 2 & $\begin{array}{l}\text { Prinsip hak } \\
\text { penguasaa } \\
\text { n Negara }\end{array}$ & $\begin{array}{l}\text { Penguas } \\
\text { aan } \\
\text { bahan } \\
\text { tamban } \\
\mathrm{g} \text { oleh } \\
\text { negara } \\
\text { (pemeri } \\
\text { ntah } \\
\text { Hindia } \\
\text { Belanda } \\
\text { ) }\end{array}$ & $\begin{array}{l}\text { Pengua } \\
\text { saan } \\
\text { bahan } \\
\text { tamban } \\
\text { g oleh } \\
\text { negara }\end{array}$ & $\begin{array}{l}\text { Penguasaan } \\
\text { bahan tambang } \\
\text { diselenggaraka } \\
\mathrm{n} \text { oleh negara } \\
\text { (Pasal 1) }\end{array}$ & 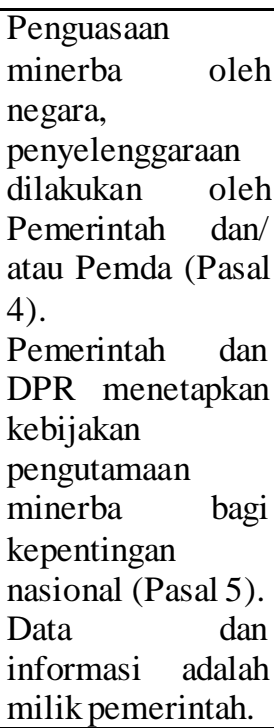 \\
\hline 3 & $\begin{array}{l}\text { Penggolon } \\
\text { g- } \\
\text { an/penge- } \\
\text { lompokan }\end{array}$ & $\begin{array}{l}\text { Perminy } \\
\text { akan } \\
\text { dan } \\
\text { bahan } \\
\text { galian } \\
\text { penting }\end{array}$ & $\begin{array}{l}\text { Bahan } \\
\text { galian } \\
\text { penting } \\
\text { dan } \\
\text { strategi } \\
\text { s }\end{array}$ & $\begin{array}{l}\text { Bahan galian } \\
\text { strategis, vital, } \\
\text { bukan strategis, } \\
\text { bukan vital } \\
\text { (Pasal 3) }\end{array}$ & $\begin{array}{l}\text { Usaha } \\
\text { pertambangan : } \\
\text { mineral dan } \\
\text { batubara; } \\
\text { Tambang mineral } \\
\text { : radio aktif, } \\
\text { logam, bukan } \\
\text { logam, batuan } \\
\text { (Pasal 34) }\end{array}$ \\
\hline
\end{tabular}

\begin{tabular}{|c|c|c|c|c|c|}
\hline & & & & & \\
\hline 4 & $\begin{array}{l}\text { Dasar } \\
\text { kegiatan } \\
\text { usaha }\end{array}$ & Konsesi & $\begin{array}{l}\text { Kuasa } \\
\text { Pertam } \\
\text { bangan }\end{array}$ & $\begin{array}{l}\text { Sistem kontrak } \\
: \quad \text { Kontrak } \\
\text { Karya, Kuasa } \\
\text { Pertambangan, } \\
\text { Surat Izin } \\
\text { Pertambangan } \\
\text { Daerah, Surat } \\
\text { Izin } \\
\text { Pertambangan } \\
\text { Rakyat (Pasal } \\
10,15)\end{array}$ & $\begin{array}{l}\text { Sistem perizinan : } \\
\text { Izin Usaha } \\
\text { Pertambangan, } \\
\text { Izin Pertambangan } \\
\text { Rakyat, Izin } \\
\text { Usaha } \\
\text { Pertambangan } \\
\text { Khusus (Pasal 35) }\end{array}$ \\
\hline 5 & $\begin{array}{l}\text { Kewenang } \\
\text { an } \\
\text { pengelolaa } \\
\text { n }\end{array}$ & $\begin{array}{l}\text { Oleh } \\
\text { pemega } \\
\text { ng } \\
\text { konsesi } \\
\text { atas izin } \\
\text { dari } \\
\text { Pemerin } \\
\text { tah } \\
\text { Hindia } \\
\text { Belanda }\end{array}$ & $\begin{array}{l}\text { Oleh } \\
\text { perusah } \\
\text { aan } \\
\text { Negara } \\
\text { sebagai } \\
\text { pemega } \\
\text { ng } \\
\text { kuasa } \\
\text { pertam } \\
\text { bangan }\end{array}$ & 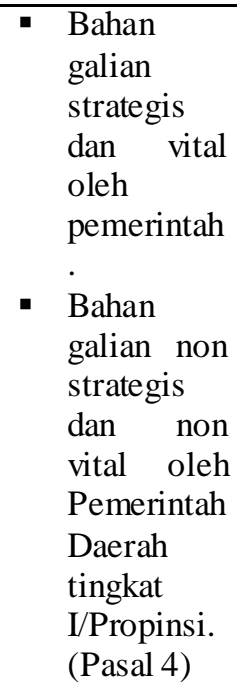 & $\begin{array}{l}\text { 21kewenang- an } \\
\text { oleh pemerintah } \\
\text { pusat, } 14 \\
\text { kewenangan oleh } \\
\text { pemerintah } \\
\text { propinsi, } 12 \\
\text { kwenangan oleh } \\
\text { pemerintah } \\
\text { Kabupaten/ Kota } \\
\text { (Pasal6-8). }\end{array}$ \\
\hline 6 & $\begin{array}{l}\text { Wilayah } \\
\text { usaha } \\
\text { pertamban } \\
\text { g-an }\end{array}$ & $\begin{array}{l}\text { Tidak } \\
\text { ditemuk } \\
\text { an } \\
\text { pengatu } \\
\text { ran } \\
\text { penentu } \\
\text { an } \\
\text { wilayah } \\
\text { pertamb } \\
\text { ang-an } \\
\end{array}$ & $\begin{array}{l}\text { Tidak } \\
\text { ditemu } \\
\text { kan } \\
\text { pengatu } \\
\text { ran } \\
\text { secara } \\
\text { terperin } \\
\text { ci }\end{array}$ & $\begin{array}{l}\text { Secara } \\
\text { terperinci tidak } \\
\text { diatur, kecuali } \\
\text { usaha } \\
\text { pertambangan } \\
\text { tidak berlokasi } \\
\text { di tempat suci, } \\
\text { kuburan, } \\
\text { bangunan dll. } \\
\text { (Pasal 16 ayat }\end{array}$ & $\begin{array}{l}\text { Bagian dari tata } \\
\text { ruang nasional } \\
\text { yang ditetapkan } \\
\text { pemerintah setelah } \\
\text { koordinasi dengan } \\
\text { Pemda dan DPR } \\
\text { (Pasal 10). } \\
\text { Terdiri dari : wil. } \\
\text { usaha } \\
\text { pertambangan, }\end{array}$ \\
\hline
\end{tabular}




\begin{tabular}{|c|c|c|c|c|c|}
\hline & & & & 1). & $\begin{array}{l}\text { wil. pertambangan } \\
\text { rakyat, wil } \\
\text { pencadangan } \\
\text { nasional (Pasal } \\
14-33 \text { ). }\end{array}$ \\
\hline 7 & $\begin{array}{l}\text { Pelaku } \\
\text { usaha }\end{array}$ & $\begin{array}{l}\text { Bangsa } \\
\text { Belanda } \\
\text { pendud } \\
\text { uk } \\
\text { Hindia } \\
\text { Belanda } \\
\text {. }\end{array}$ & $\begin{array}{l}\text { Perusah } \\
\text { aan } \\
\text { Negara. }\end{array}$ & $\begin{array}{l}\text { Investor } \\
\text { nasional, } \\
\text { investor asing. }\end{array}$ & $\begin{array}{l}\text { IUP bagi badan } \\
\text { usaha } \\
\text { (PMA/PMDN), } \\
\text { Koperasi, } \\
\text { perseorangan } \\
\text { (Pasal 38). } \\
\text { IPR bagi } \\
\text { penduduk lokal, } \\
\text { koperasi (Pasal } \\
\text { 67). } \\
\text { IUPK bagi badan } \\
\text { usaha berbadan } \\
\text { hukum Indonesia } \\
\text { dg. prioritas pada } \\
\text { BUMN/BUMD } \\
\text { (Pasal 75). }\end{array}$ \\
\hline
\end{tabular}

Data yang telah diolah. 
B. Penyelesaian Sengketa Pertambangan Setelah Berlakunya Undang-Undang Nomor 4 Tahun 2009 tentang Pertambangan Mineral dan Batubara.

Dalam perkembangannya setelah lahirnya peraturan perundang-undangan yang mengatur tentang pertambangan, khususnya Undang-Undang Nomor 4 Tahun 2009 tentang Pertambangan Mineral dan Batubara, penyelesaian sengketa sudah ditentukan sejak awal melalui ketentuan-ketentuan dalam Undang-Undang Nomor 4 Tahun 2009 tentang Pertambangan Mineral dan Batubara dan tidak lagi didasarkan oleh kesepakatan para pihak dalam kontrak.

Jika mencermati ketentuan mengenai penyelesaian sengketa yang terdapat pada UndangUndang Nomor 4 Tahun 2009 tentang Pertambangan Mineral dan Batubara, hanya ada satu pasal yaitu Pasal 154 yang mengatur secara tegas tentang penyelesaian sengketa. Ketentuan penyelesaian sengketa tersebut boleh dikatakan sangat umum serta hanya mencakup sengketa antara pemerintah dengan investor, baik investor dalam negeri maupun investor asing. Sementara itu tidak ada penjelasan mengenai ketentuan Pasal 154 tersebut. Namun demikian, selain Pasal 154 diketahui bahwa Pasal 166 juga mengatur penyelesaian masalah dampak lingkungan, walaupun tidak secara spesifik menyebutkan sebagai "sengketa". Adapun rumusan Pasal 166 Undang-Undang Nomor 4 Tahun 2009 adalah sebagai berikut :

"Setiap masalah yang timbul terhadap pelaksanaan IUP, IPR, dan IUPK yang berkaitan dengan dampak lingkungan diselesaikan sesuai dengan ketentuan peraturan perundang-undangan".

Dalam Pasal 154 Undang-Undang Nomor 4 Tahun 2009 tentang Pertambangan Mineral dan Batubara, ditentukan cara penyelesaian sengketa yang timbul antara badan usaha dengan pemerintah dalam IUP, IPR atau IUPK. Ada dua cara yang digunakan untuk menyelesaikan sengketa antara pemegang IPR, IUP, dan IUPK dengan pemberi IPR, IUP atau IUPK, yaitu pengadilan atau arbitrase dalam negeri sesuai dengan ketentuan peraturan perundang-undangan.

\section{Penyelesaian Sengketa Melalui Pengadilan}

Perizinan merupakan suatu keputusan tata usaha negara karena memenuhi unsur-unsur yaitu, individual, final, and concrete. Penyelesaian sengketa izin usaha pertambangan merupakan penyelesaian sengketa antara pemegang izin usaha pertambangan dengan pemerintah. Mengingat izin usaha pertambangan tergolong ke dalam sebuah keputusan tata usaha negara, maka penyelesaian sengketa izin usaha pertambangan dilakukan melalui Pengadilan Tata Usaha Negara (PTUN) berdasarkan Pasal 1 angka 10 Undang-Undang Nomor 51 Tahun 2009 tentang Perubahan Kedua atas Undang-Undang Nomor 5 Tahun 1986 tentang Peradilan Tata Usaha Negara jo. Undang-Undang Nomor 9 Tahun 2004 tentang Perubahan atas Undang-Undang Nomor 5 Tahun 1986 tentang Peradilan Tata Usaha Negara jo. Undang-Undang Nomor 5 Tahun 1986 ("UU PTUN"), yaitu :

“ Sengketa Tata Usaha Negara adalah sengketa yang timbul dalam bidang tata usaha negara antara orang atau badan hukum perdata dengan badan atau pejabat tata usaha negara, baik di pusat maupun di daerah, sebagai akibat dikeluarkannya keputusan tata usaha negara, termasuk sengketa kepegawaian berdasarkan peraturan perundang-undangan yang berlaku".

\section{Penyel esaian Sengketa Melalui Arbitrase.}

Dalam suatu hubungan bisnis atau perjanjian, selalu ada kemungkinan timbulnya sengketa. Sengketa yang perlu diantisipasi adalah mengenai cara melaksanakan isi perjanjian yang dituangkan dalam klausul-klausul perjanjian ataupun disebabkan hal lain. ${ }^{16}$ Demikian halnya kegiatan usaha di bidang pertambangan, ketika timbul sengketa yang bersumber dari pemberian izin di sektor pertambangan yaitu IPR, IUP, dan IUPK maka penyelesaian sengketa dapat ditempuh melalui pengadilan yaitu Pengadilan Tata Usaha Negara, disamping itu berdasarkan Pasal 154 Undang-Undang Nomor 4 Tahun 2009 tentang Pertambangan Mineral dan Batubara, penyelesaian sengketa yang berhubungan dengan izin kegiatan pertambangan juga dapat diselesaikan melalui arbitrase.

Berdasarkan Pasal 1 angka 1 UndangUndang Nomor 30 Tahun 1999 tentang Arbitrase dan Alternatif Penyelesaian Sengketa, pengertian arbitrase adalah merupakan cara penyelesaian suatu sengketa perdata di luar pengadilan umum yang didasarkan pada perjanjian arbitrase yang dibuat secara tertulis oleh para pihak yang bersengketa.

Adapun objek perjanjian arbitrase (perjanjian mengenai pilihan penyelesaian sengketa melalui arbitrase) berdasarkan Pasal 5 ayat (1) Undang-Undang Nomor 30 Tahun 1999 tentang Arbitrase dan Alternatif Penyelesaian Sengketa adalah sengketa di bidang perdagangan dan mengenai hak yang menurut hukum dan peraturan perundang-undangan dikuasai sepenuhnya oleh pihak yang bersengketa. Lebih lanjut dalam Pasal 5 ayat (2) Undang-Undang Nomor 30 Tahun 1999 tentang Arbitrase dan Alternatif Penyelesaian Sengketa dirumuskan bahwa sengketa yang tidak dapat diselesaikan melalui arbitrase adalah sengketa yang menurut peraturan perundangundangan tidak dapat diadakan perdamaian.

${ }^{16}$ Gatot Soemartono, Arbitrase dan Mediasi di Indonesia. (Jakarta : PT Gramedia Pustaka Utama, 2006), hlm. 3. 
Dari beberapa rumusan tersebut di atas, dapat dijelaskan bahwa arbitrase sebenarnya hanya menyelesaikan sengketa perdata bukan sengketa Tata Usaha Negara. Selain itu bahwa sengketa izin tersebut tidak termasuk sengketa yang dapat diselesaikan melalui arbitrase sebagaimana disebutkan dalam Pasal 5 ayat (1) dan (2) UndangUndang Nomor 30 Tahun 1999 tentang Arbitrase dan Alternatif Penyelesaian Sengketa. Bahwa izin bukan merupakan objek perdagangan, kemudian terbitnya izin karena adanya keputusan pemerintah yang sifatnya adalah sepihak. Oleh karena kuasa pada perizinan berada pada satu pihak, dalam hal ini adalah pemerintah, sehingga tidak bisa disebut sebagai para pihak.

Dalam hal adanya gugatan perbuatan melawan hukum yang kemudian mengakibatkan adanya ganti kerugian dari investor pertambangan yang telah dirugikan sebagai akibat dicabutnya izin atau tidak dikeluarkannya izin dari pejabat tata usaha negara di bidang pertambangan yang didasarkan pada pelaksanaan IUP, IPR, dan IUPK sebagai keseluruhan kegiatan pertambangan, maka sengketa tersebut dapat diselesaikan melalui arbitrase. ${ }^{17}$

Pada saat penerbitan izin yang berbentuk keputusan Tata Usaha Negara yang menyangkut izin pertambangan, dalam klausulanya tidak disebutkan mengenai mekanisme penyelesaian sengketa. Oleh karena itu yang bisa ditempuh adalah dengan membuat kesepakatan untuk penyelesaian sengketa dalam suatu perjanjian arbitrase setelah terjadinya sengketa. Dengan tindakan tersebut, maka akan timbul kendala yaitu mungkinkah suatu perbuatan hukum yang dilakukan antara pihak pemerintah dengan penerima izin pertambangan membuat kesepakatan dalam bentuk perjanjian arbitrase.

\section{Penyelesaian Sengketa Melalui ADR (Alternative Dispute Resolution).}

ADR atau alternatif penyelesaian sengketa adalah sekumpulan prosedur atau mekanisme yang berfungsi memberi alternatif atau pilihan suatu cara penyelesaian sengketa melalui bentuk APS/ arbitrase agar memperoleh putusan akhir dan mengikat para pihak. ${ }^{18}$

Adapun ciri atau karakter mekanisme penyelesaian sengketa melalui ADR (Alternative Dispute Resolution) meliputi :

1. Informality (tidak formal);

2. Aplication of equity (penerapan keadilan);

3. Direct participation and communication between

${ }^{17}$ Agung Cahyono : "Tinjauan Yuridis Penyelesaian Sengketa Pertambangan", Wawancara pada Kementerian ESDM, Skripsi, Fakultas Hukum UI, 2011, hlm. 106-107.

${ }^{18}$ H. Priyatna Abdurrasyid, Loc. Cit. disputants (partisipasi dan komunikasi langsung para pihak). ${ }^{19}$

Pada dasarnya, proses ADR merupakan proses yang tidak formal dibandingkan dengan proses pengadilan. Dalam beberapa kasus, prosedur ADR adalah tidak kaku, tidak perlu adanya gugatan resmi, tidak perlu adanya dokumentasi panjang lebar, atau tidak perlu adanya pembuktian. Ketidakformalan ini menarik dan penting untuk meningkatkan akses penyelesaian sengketa alternatif bagi masyarakat yang mungkin terintimidasi apabila berpartisipasi dalam sistem formal.

Prinsip penyelesaian sengketa melalui mekanisme ADR adalah dalam rangka penerapan keadilan dari para pihak melalui pihak ketiga, atau dinegosiasikan antara para pihak yang bersengketa berdasarkan prinsip-prinsip kesamaan dalam kasus tertentu. Peran serta para pihak secara langsung dalam menyelesaikan dan merancang penyelesaian sengketa atau dialog langsung antara pihak yang bersengketa adalah karakteristik dari ADR. Secara garis besar, mekanisme ADR dikategorikan menjadi empat, yaitu negosiasi, konsiliasi, mediasi, dan arbitrase. ${ }^{20}$

Mekanisme penyelesaian sengketa melalui ADR sesungguhnya sesuai apabila diterapkan pada sengketa yang timbul berdasarkan hubungan hukum dari perjanjian (perdata), sebagaimana pengaturan kegiatan pertambangan berdasarkan Undang-Undang Nomor 11 Tahun 1967 tentang Ketentuan-Ketentuan Pokok Pertambangan yaitu Kontrak Pertambangan, Kontrak Karya, PKP2B. Namun dengan berlakunya Undang-Undang Nomor 4 Tahun 2009 tentang Pertambangan Mineral dan Batubara yang mengatur kegiatan usaha pertambangan atas dasar izin yaitu IUP, IPR, dan IUPK, maka mekanisme penyelesaian sengketa melalui $\mathrm{ADR}$ adalah tidak tepat. Hal ini dikarenakan bahwa perizinan masuk dalam lingkup adminitrasi negara, sehingga untuk penyelesaian sengketa harus melalui Pengadilan Tata Usaha Negara dan arbitrase sebagaimana dirumuskan dalam Pasal 154 Undang-Undang Nomor 4 Tahun 2009 tentang Pertambangan Mineral dan Batubara.

D. Penyelesaian Sengketa Melalui Lembaga Adat.

19 Patricia Alexander, Alternative Dispute Resolution Practitioners Guide, (Washington DC : Democracy and Governance Bureau for Democracy, Conflict, and Humanitarian Assistance U.S. Agency for International Development, 1999), hlm. 5 dalam H. Salim HS, Hukum Penyelesaian Sengketa Pertambangan di Indonesia (Bandung : Pustaka Rekacipta, 2013), hlm. 225.

${ }^{20} \mathrm{Ibid}$, hlm. 5. 
Penyelesaian sengketa melalui lembaga adat merupakan penyelesaian sengketa dengan menggunakan institusi yang hidup dan berkembang dalam masyarakat hukum adat. Pada umumnya dalam masyarakat hukum adat dikenal lembaga dan nilai-nilai kearifan lokal yang berkaitan dengan penyelesaian sengketa adat.

Mekanisme penyelesaian sengketa melalui lembaga adat biasanya dipilih ketika sengketa tersebut bersumber dari pemanfaatan lahan untuk kegiatan pertambangan yang bersinggungan dengan hak-hak masyarakat adat (tanah adat) maupun pemanfaatan sumber daya alam. Berdasarkan hasil penelitian yang dilakukan oleh H. Salim atas kasus kegiatan eksplorasi oleh PT Newmont Nusa Tenggara di Elang Dodo, dapat dikemukakan bahwa dengan pranata adat diupayakan untuk dapat menyelesaikan sengketa antara masyarakat Labangkar dengan PT Newmont Nusa Tenggara. ${ }^{21}$

\section{PENUTUP}

Simpulan

1. Perkembangan Pengaturan Kegiatan Usaha Bidang Pertambangan di Indonesia.

Ketentuan yang mengatur sumber daya alam dirumuskan dalam Pasal 33 ayat (3) UndangUndang Dasar Negara Republik Indonesia Tahun 1945. Dengan dirumuskannya penguasaan oleh negara untuk sumber daya alam khususnya pertambangan maka dapat digunakan sebagai instrumen hukum yang memberikan kepastian adanya faktor kendali negara terhadap pengelolaan di bidang pertambangan. Adapun perkembangan pengaturan kegiatan usaha bidang pertambangan di Indonesia diawali dengan berlakunya Indische Mijnwet 1899 (IM 1899) pada masa pemerintahan Hindia Belanda; setelah kemerdekaan kemudian ditetapkan peraturan pengelolaan bidang pertambangan dengan diterbitkannya Peraturan Pemerintah Pengganti Undang-Undang (Perpu) Nomor 37 Tahun 1960 yang mengatur khusus bidang Pertambangan, kemudian pemerintah Republik Indonesia menerbitkan pula Peraturan Pemerintah Pengganti Undang-Undang (Perpu) Nomor 44 Tahun 1960 yang mengatur khusus tentang Minyak dan Gas Bumi, kemudian Peraturan Pemerintah Pengganti Undang-Undang (Perpu) Nomor 37 Tahun 1960 menjadi UndangUndang Nomor 37 Prp. Tahun 1960 tentang Pertambangan; kemudian diterbitkan UndangUndang Nomor 11 Tahun 1967 tentang KetentuanKetentuan Pokok Pertambangan, khusus mengenai kontrak karya pada pengusahaan pertambangan batubara, diatur dalam Peraturan Pemerintah Nomor 75 Tahun 1996 tentang Ketentuan Pokok Perjanjian Karya Pengusahaan Pertambangan

${ }^{21}$ Ibid, hlm. 242.
Mineral dan Batubara (PKP2B); pada akhir tahun 2008 pemerintah mengesahkan Undang-Undang Nomor 4 Tahun 2009 tentang Pertambangan Mineral dan Batubara (UU Minerba), jenis izin usaha pertambangan menurut Undang-Undang Nomor 4 Tahun 2009, lebih sederhana dibandingkan dengan jenis izin pertambangan yang diatur dalam Undang-Undang Nomor 11 Tahun 1967, yaitu hanya terdiri dari 3 (tiga) macam izin, sebagaimana diatur dalam Pasal 35 UndangUndang Nomor 4 Tahun 2009, bahwa usaha pertambangan dilaksanakan dalam bentuk:
a. Izin Usaha Pertambangan, disingkat IUP;
b. Izin Pertambangan Rakyat, disingkat IPR; dan
c. Izin Usaha Pertambangan Khusus, disingkat IUPK.

2. Mekanisme Penyelesaian Sengketa Bidang Pertambangan Dalam Rangka Menciptakan Kepastian Hukum dan Keadilan.

a. Mengingat saat ini masih ditemui pengaturan usaha pertambangan berdasarkan Undang-Undang Nomor 11 Tahun 1967 sebagaimana dirumuskan dalam Pasal 169 Undang-Undang Nomor 4 Tahun 2009, maka mekanisme penyelesaian sengketa yang ditempuh para pihak adalah melalui : Pertama Proses Non Adjudikasi, yaitu negosiasi, konsiliasi, dan mediasi ; Kedua Proses Adjudikasi, yaitu litigasi dan arbitrase.

b. Penyelesaian Sengketa Pertambangan setelah berlakunya Undang-Undang Nomor 4 Tahun 2009 diatur dalam Pasal 154 , yaitu :

1) Melalui Pengadilan, yaitu melalui Pengadilan Tata Usaha Negara (PTUN) berdasarkan Pasal 1 angka 10 Undang-Undang Nomor 51 Tahun 2009 jo. Undang-Undang Nomor 9 Tahun 2004 jo. Undang-Undang Nomor 5 Tahun 1986.

2) Melalui Arbitrase dalam negeri. Menurut pendapat penulis, sengketa yang berhubungan dengan izin pertambangan tidak termasuk sengketa yang dapat diselesaikan melalui arbitrase. Namun dalam hal adanya gugatan perbuatan melawan hukum yang kemudian mengakibatkan adanya ganti kerugian, maka sengketa tersebut dapat diselesaikan melalui arbitrase.

c. Penyelesaian Sengketa Melalui ADR (Alternative Dispute Resolution), dikategorikan menjadi empat, yaitu negosiasi, konsiliasi, mediasi, dan arbitrase. 
d. Penyelesaian Sengketa Melalui Lembaga Adat, biasanya dipilih ketika sengketa tersebut bersumber dari pemanfaatan lahan untuk kegiatan pertambangan yang bersinggungan dengan hak-hak masyarakat adat (tanah adat) maupun pemanfaatan Saran sumber daya alam.

1. Mencermati perkembangan peraturan perundang-undangan di bidang kegiatan usaha pertambangan yang sering berubah, seharusnya pemerintah mengambil sikap dalam setiap rencana melakukan perubahan peraturan perundang-undangan dengan tetap memperhatikan aspek filosofis, asas manfaat dan mempertimbangkan perkembangan yang akan datang.

2. Pemerintah yang mempunyai peran utama, baik sebagai regulator, supervisor, fasilitator dan bahkan kadang-kadang sebagai pihak dalam sengketa pertambangan agar bertindak secara proaktif, netral, imparsial dan adil untuk meningkatkan kepercayaan kepada pemerintah.

3. Dengan adanya berbagai permasalahan terkait dengan mekanisme penyelesaian sengketa di bidang pertambangan khususnya Pasal 154 UU Minerba, maka penulis menyarankan agar pembuat kebijakan dapat dengan segera melakukan sinkronisasi terhadap peraturan terkait yaitu UU Penanaman Modal dan UU Arbitrase.

4. Pemerintah harus menciptakan keseimbangan atas kepentingan stakeholder yang terkait dengan kegiatan pertambangan, sehingga masing-masing pihak akan merasa terayomi dan terakomodasikan kepentingannya untuk terwujudnya keadilan dan kepastian hukum.

\section{DAFTAR PUSTAKA}

\section{BUKU}

Ali, Zainudin. 2010. Metode Penelitian Hukum. Jakarta : Sinar Grafika.

Bambang Yunianto, Rochman Saefudin dan Ijang Suherman. 2004. Kebijakan Sektor Energi dan Sumberdaya Mineral dan Implikasinya Terhadap Pertambangan Emas, dalam Penambangan dan Pengolahan Emas di Indonesia . Bandung : Puslitbang Teknologi Mineral dan Batubara.

Dean G. Pruitt dan Jeffrey Z. Rubin. 2004. Konflik

Sosial. Yogyakarta : Pustaka Pelajar.

Gatot Soemartono. 2006. Arbitrase dan Mediasi di Indonesia. Jakarta: PT Gramedia Pusaka Utama.

Jaja Ahmad Jayus. 2001. Lembaga Perizinan Sebagai Sarana Pengendalian Investasi dalam Implementasi Otonomi Daerah. Bandung : Tesis.

Lawrence M. Friedman. 2001. American Law an Introduction. (Hukum Amerika : Sebuah Pengantar. Penerjemah: Wisnu Basuki). Jakarta : Tata Nusa.

Nandang Sudrajat. 2010. Teori dan Praktik Pertambangan Indonesia Menurut Hukum. Yogyakarta : Pustaka Yustisia.

Priyatna Adurrasyid H. 2002. Arbitrase dan Alternatif Penyelesaian Sengketa Suatu Pengantar. Jakarta: PT Fikahati Aneska.

Salim HS. 2012. Hukum Pertambangan Mineral dan Batubara. Jakarta : Sinar Grafika. .2013. Hukum Penyelesaian Sengketa Pertambangan di Indonesia. Bandung : Pustaka Reka Cipta.

Utrecht. 1982. Pengantar Hukum Administrasi Negara Indonesia. Jakarta: Sinar Grafika.

\section{PERATURAN PERUNDANG-UNDANGAN}

Indische Mijnwet 1988 (Mining act of the Indies); Undang-Undang Nomor 37 Prp. Tahun 1960 tentang Pertambangan;

Undang-Undang Nomor 11 Tahun 1967 tentang Ketentuan-Ketentuan Pokok Pertambangan;

Undang-Undang Nomor 30 Tahun 1999 tentang Arbitrase dan Alternatif Penyelesaian Sengketa;

Undang-Undang Nomor 4 Tahun 2009 tentang Pertambangan Mineral dan Batubara;

Undang-Undang Nomor 32 Tahun 2009 tentang Perlindungan dan Pengelolaan Lingkungan Hidup. 